Article

\title{
Researching Child Authors: Which Questions (not to) Ask
}

\author{
Elisabeth Wesseling
}

Faculty of Arts and Social Sciences, Centre for Gender and Diversity, Maastricht University Grote Gracht 80, 6211 SZ Maastricht, The Netherlands; lies.wesseling@maastrichtuniversity.nl

Received: 4 February 2019; Accepted: 4 April 2019; Published: 5 May 2019

check for updates

\begin{abstract}
It used to be taken for a given fact that children's literature is written by adults for children. This assumption is contested by the emergence of "another children's literature", namely literature about, for, and by children. Facilitated by digital platforms, this alternative type of children's literature is gathering momentum, compelling us to rethink the (im)possibilities of children's creative agency. As research into children's literature is largely premised upon the asymmetry between adult authorship and juvenile readership, we need to rethink some fundamental tenets of this academic field in order to come to terms with child authorship. This article reviews leading publications on the topic, to address the question of how we can best acknowledge, facilitate, and appreciate children's creative agency as an indispensable dimension of their emergent citizenship. Methodological deliberations are illustrated with references to primary works by child authors about topical societal issues such as ethnic conflict, homelessness, and migration. Its aim is not so much to provide a complete survey of all available publications on the topic, but rather to stake out representative publications that exemplify more and less fruitful approaches to the problem at hand.
\end{abstract}

Keywords: child authorship; children's agency; intergenerational collaboration; hermeneutics of suspicion; kinship model of childhood; discourse tagging

\section{Introduction: Contesting the Asymmetry of Children's Literature}

Ever since the publication of Jacqueline Rose's seminal work Peter Pan, or the Impossibility of Children's Literature (Rose 1984), children's literature scholars have been debating the foundational parameters of their research field, i.e., the (im)possibility of comprehending children and childhood well enough for adult authors to effectively attune and cater to juvenile audiences. Rose famously argued that authors of children's literature assume too easily that children are fully knowable to adults, to the extent that it would be possible for the latter to create authentic representations of juvenile behaviors and frames of mind. Children are necessarily opaque to adults according to Rose; witness, for example, adult struggles to recuperate childhood experiences in psycho-analysis, that never fully succeed. Consequently, child characters created by adult authors are largely projection screens for adult fantasies, fixations, fears, and desires, which are imposed on child readers from above.

Treading in Rose's footsteps, leading researchers such as Nodelman (1992a) and Nikolajeva (2010) have likewise argued that children's literature basically presents adult preoccupations with childhood, thereby taking in, colonizing, repressing or even silencing its youthful readership. From this perspective, children's literature is informed by a power hierarchy between adult authors and young readers which thwarts the latter's agency. Being spoken for, rather than speaking for oneself, is a familiar mode of repression, however well-intentioned. The upshot of this line of argumentation is ultimately a rather categorical verdict on the whole phenomenon of children's literature as inherently repressive. 
This radical deconstruction of the validity and viability of children's literature has been considerably nuanced by various theoretical and historical deliberations. One may observe, for example, that Rose, Nodelman, and Nikolajeva also project an ideology of childhood, by assuming that child readers can only be passive reflectors of adult projections (Bernstein 2011a). The assumption that children's ways of relating to the world are totally opaque to adults is just another way of 'othering' and mythologizing children. The image of the defenseless child is as much an adult construct as notions of the 'ignorant' child eventually becoming rational, the 'innocent' child which sadly loses its divine aura as it becomes contaminated by society, and so on (Reimer and Peters 2011, see also Rudd and Pavlik 2010).

But the most vital critiques of the supposed impossibility of children's literature come from researchers who do not only counter Rose cum suis on theoretical grounds, but also on the basis of empirical research, most notably historical inquiry. Rather than debating the much-maligned asymmetry of children's literature in the abstract, scholars such as Gubar (2009), Alexander and McMaster (2010), Bernstein (2011b), and Ford Smith (2017) have entered into the archives to investigate what children's role in the construction of children's narratives may actually have been. Their conclusion is that literary history has unduly marginalized children's creative contributions to a literature of their own, and that many classics of Anglophone children's literature have in fact resulted from creative partnerships between juvenile and adult authors and illustrators. Sadly, the names of the first have not made their way to the book covers, an omission that was instrumental in effacing their contributions. Victoria Ford Smith relates this effacement to the dominance of the Romantic idea of the author as a 'solitary genius' in Western literature and culture as outlined by Stillinger (1991) (Ford Smith 2017, p. 240), which is hardly amenable to an appreciation of the collaborative dimensions of creative work.

Importantly, Rose never considered the possibility of a child-authored children's literature past or present. However, this phenomenon is difficult to ignore, as the digital context has opened up new opportunities for the creative endeavors of young people. It is not just that the world wide web provides children with easily accessible tools for writing back at children's literature produced by adults, Harry Potter fan fiction being the most prominent manifestation of this type of literary production (Tosenberger 2007). It is also that new reproduction technologies, such as print-on-demand, have reduced the commercial risks for publishers to engage in the adventure of facilitating children to write about and for themselves (Cumming 2017). Furthermore, the concept of the author as a 'solitary genius' is losing ground under the impact of new digital fora, where the distinction between writers and readers is becoming increasingly blurry; witness the introduction of neologisms such as "wreader" (Landow 1992) or "prosumer" (Ritzer and Jurgenson 2010). In the online world, creative intergenerational partnerships and even self-published young authors are becoming increasingly common.

This article reconsiders some deeply entrenched positions concerning the (un)knowability of children and the (im)possibility of children's literature. Does the phenomenon of child authorship open up a viable alternative for the supposedly repressive nature of mainstream children's literature? What sort of questions could scholars fruitfully pose to child-authored literature, and, conversely, which questions are better not raised? After sketching some contemporary forms of child authorship, I proceed to discuss two sets of methodological dos and don'ts. The idea behind this set-up is that I do not only want to criticize but also outline promising perspectives on the topic at hand. I shall argue that constructive approaches to child authorship successfully operationalize Marah Gubar's "kinship model of childhood" (Gubar 2011, 2013, 2016), which stakes out a middle ground between the "deficiency model" and the "difference model" of childhood. The first stipulates that children are basically similar, but underdeveloped versions of adults, legitimatizing top-down, adult-oriented pedagogies that are designed for remedying children's deficiencies as quickly and effectively as possible. The second model claims that children are wholly other, which supports a pedagogy of non-interference, aimed at keeping children in their own world as long as possible. The kinship model figures children as related to adults. This view allows for differences between age groups without postulating that children are in 
a different category altogether. It acknowledges dependencies of children on adults and differences in power the two, without entirely foregoing the possibility of some degree of child agency and of authentic partnerships between age groups. This means that creative intergenerational collaboration need not be categorically equated with repression, colonization or silencing, as the difference model suggests. It all depends. Therefore, this article argues that fine-grained empirical research rather than apodictic theorizing is called for.

\section{A Literature of Their Own?}

Digital transformations of the media-scape have given a new impetus to former, rather short-lived and scant attempts by innovative publishers such as Annick Press in Canada (originally called 'Books by Kids') to publish literature about, for, and by children (Wilks and Millyard 1975). These attempts came too early, one might surmise with the advantage of hindsight, standing little chance of success within the parameters of print. Annick Press is now once more publishing stories that have come out of intergenerational collaboration (cf. Kamara and McClelland 2008; Jordan-Fenton and Pokiak-Fenton 2010, 2011, see also Edwards and Saltman 2010), and a similar phenomenon can be observed on the European literary scene, for instance, in the Netherlands. Significantly, the leading Dutch children's literature publisher Querido launched a new series in 2008, the so-called Slash Series (not to be confused with slash fiction), which publishes novels for adolescents that feature two names on the cover on both sides of a slash, coupling the name of a well-established author of children's or young adult fiction to that of a youthful storyteller or informant. It is a series in life writing, that is, it narrates the autobiographies of the youngsters whose names appear after the slash. The idea is that the informants provide the story materials and that the experienced authors give these materials aesthetic form.

The Slash Series makes a concerted effort to broach painful, tabooed, and politically sensitive topics such as migration, homelessness, addiction, growing up away from one's family with foster parents or in an institution, and youth criminality. According to the initiator of the Slash Series, the celebrated children's author Edward van de Vendel, its aim is twofold. On the one hand, he hopes that it will push adult authors closer to the (often grim) realities facing today's young people, while on the other hand, it aims at "the possible effect of pulling young adults closer to literature as well" (Van de Vendel 2006, p. 127), as he firmly believes that "reality, verisimilitude, honesty still have a growing magnetic power". Van de Vendel hopes the series will help to close the age gap between children and adults: "Children's literature can make clear how close we are to each other. How our breath, once blown, always, always mingles" (Van de Vendel 2006, p. 126).

Another salient example of promoting child authorship is provided by the Dutch publisher Boekscout (www.Boekscout.nl), which caters to its customers by print-on-demand directly through its webshop, circumventing bookstores. It publishes both adult and child authors, who feature side by side in the books on offer, without being cordoned off into separate categories. The website of Boekscout emphatically encourages young authors to submit manuscripts, and it currently has some 145 novels by young people within an age range between 9 and 18 on sale. These deal with a great variety of themes, ranging from relatively light-hearted stories about the ups and downs in friendships between girls to highly serious treatments of ethnic conflict, asylum seeking, and migration, within an equally wide spectrum of genres, most notably fantasy, the detective story, the pony story, life writing ((auto-)biography), and the Gothic novel.

Melissa van Lijssel's novel Een leven vol verdriet: Gevlucht uit Joegoslavië (A Life full of Misery: Escape from Jugoslavia) (2016) provides an interesting counterpart to the set-up of the Slash Series, in that the child author is the facilitator of the adult's memoir here, rather than the other way around. This novel is based on the real-life story of a woman called 'Alice', who fled from the civil war in the former republic of Jugoslavia to the Netherlands in her teens. This means she is bound to be the author's senior by twenty years or so, as Van Lijssel was 12 when her first novel came out in 2016. In a radio broadcast by a local broadcasting company, Van Lijssel reveals that she has known 'Alice' all her 
life, and that the latter at some point in their relationship divulged her whole life story to her. This is what turned her into an author, Van Lijssel states (https://www.omroepbrabant.nl/nieuws/221597/ Melissa-12-schrijft-boek-over-Joegoslavische-vluchteling-Het-schrijven-was-soms-heftig).

It is a remarkable work, in that the youthful author gives a highly detailed, empathetic, and convincing account of Alice's feelings and perceptions over a period of around ten years as she goes through the trials of dealing with cold, rejecting parents, leaving her home country behind in the company of unsupportive adults, finding her way around in a new society and culture, searching for someone to love in that new land, choosing an education trajectory and embarking on a career, and so on. Twelve-year-olds are rarely credited with being capable of relating to the complex feelings of a thirty-something, but Van Lijssel provides evidence to the contrary. The novel also stands out in that it departs from the conventional plot structure of the home-away-home sequence characteristic of children's literature by adults according to Nodelman (1992b). The story does not end when Alice has finally found a new home away from home with a newlywed husband, a house of her own, and a promising career. In fact, it ends rather unhappily, with the whole homely structure falling apart once again, due to the death of Alice's younger sister, for whom she feels highly responsible, given their inadequate parents. Een leven vol verdriet ends on a rather somber note: "I felt the ground part underneath my feet. It kept on sliding down and dragged me along. It resembled the same mud and the same pit I had been scrambling out of over the last couple of years.... Now I have fallen back in again in one go. Into a deep and dark pit" (Van Lijssel 2016, p. 170).

Clearly, a refugee's sorrows are not necessarily over once they have found their way around the country of destination, as this young author realizes all too well, refraining from 'all's well that ends well' closure. Her book closely resembles Edward van de Vendel's and Anoush Elman's De gelukvinder (The Fortune Finder) in this respect. Its main character, Hamayun, is an adolescent boy who flees from the Taliban regime in Afghanistan with his family. The novel tells the story of their dangerous journey from Afghanistan to the Netherlands, where they become caught up in a gruelingly long and prolonged asylum-seeking procedure. The novel ends somewhere halfway through this tortuous procedure, without providing an answer to the question of whether Hamayun and his family will be allowed to stay in their country of arrival or not. Apparently, adolescents do not consider a happy ending as imperative as many adult authors and critics of children's literature do (Craigh 2014).

\section{Beyond the Search for Categorical Differences between Writings by Children and Adults}

Now that a growing corpus of child-authored literature is becoming available, it might be tempting to compare it to adult-authored children's literature past or present, to identify the distinctive features of this literary mode. The concept is a flawed one and makes us particularly susceptible to the deeply ingrained cultural tendency to mythologize children as a separate species vastly inferior or superior to adults, which is always dogging the study of children's literature and childhood studies at large. For example, child authors may be regarded as Romantic geniuses who are still in touch with the divine sources of inspiration, as opposed to their adult counterparts (Kittridge 2011). Or, conversely, their writing may be perceived as indicative of the cognitive and artistic deficiencies that they still need to grow out of. Child authors, however, do quite simply what every other author does, namely seeking entry into the republic of letters by imitating and emulating inspiring examples. Since adult authors outnumber child authors, these examples are far more likely to be provided by the first category. This is clearly visible in the works by child authors on offer with Boekscout, which conform to the templates of well-established genres and celebrated authors, basically the books that child authors like to read themselves, and that they therefore strive to emulate. Moreover, the child authors published by Boekscout are coached and edited by adult editors, as the website clearly announces in its address to aspiring young authors, and these editors are also likely to work within the parameters of familiar genres. Clearly, then, child-authored books cannot provide us with a privileged point of entry into 'authentic' childhood, whatever that may be. Victor Watson's conclusion to his open-minded and carefully argued comparison of some five Anglophone novels by young authors published between 
1919 and 1963 to children's books authored by adults in the same genres and periods, therefore comes, as no surprise: "I think it can be said it [children's literature by children, EW] displays an absence of that interest in the larger perspective of time, change and character growth ... In all other respects, though, they differ from one another as much as novels by adults differ from another" (Watson 2000, p. 63). This seems like a sound conclusion to me, which is not really conducive to further inquiry along these same lines.

A more promising alternative to the quest for categorical differences between these two types of children's literature is offered by "discourse tagging" (Rogers and Marshall 2012; Marshall and Rogers 2017). The term is somewhat confusing, as it evokes associations with coding methods from (socio)linguistics, as used in conversation analysis, thematic analysis or content analysis. Theresa Rogers and Elizabeth Marshall's approach, however, does not have all that much to do with these quantitative methods. Rather, it draws on literary applications of critical discourse analysis, as exemplified by Mills [1991] (1993). Their approach implies that one assembles heterogeneous but related fictional genres dealing with a specific societal issue, for instance, homelessness of minors. Thus, Rogers and Marshall have assembled canonized novels for and by adults about homelessness of young people, such as Oliver Twist by Charles Dickens, young adult fiction by adult authors on the topic, such as Cynthia Voigt, as well as poetry, novels, and life writing by adult and youthful experiential experts, published in zines by homeless people. These diverse bodies of literature are subsequently compared to each other to identify shared "structuring statements", defined as follows: "A structuring statement, in its simplest form, can be as common as an aphorism that is often assumed to be self-evident and true, such as 'boys will be boys'" (Rogers and Marshall 2012, p. 726). In this definition, structuring statements are identical to what is called commonplaces or 'topoi' in the rhetorical tradition. Tracking shared commonplaces across diverse literary genres on homelessness, including writings by children, may reveal a society's deepest assumptions about the causes, nature, and effects of homelessness, shedding light on fundamental issues such as the question of whether this condition is to be attributed to individual failure or to societal circumstances, whether its effects are wholly negative or mixed, etc. This seems like an appealing way of making the affinities and differences between (children's) literature by adults and young people productive for cultural inquiry, taking them equally seriously without essentializing either one of them. The only objection one could raise here is that "discourse tagging" as advocated by Rogers and Marshall is still a rather impressionistic method that does not come anywhere near the rigor and meticulousness of its linguistic counterparts. The authors remain silent on the question of how to identify the so-called "structuring statements". They could have profited more fully from the rich tradition of rhetorical analysis (Eisenhart and Johnstone 2008) and from methodological literature on coding in discourse analysis (cf. Gill 2000) here. This would imply that one does not limit the scope of one's analysis to commonplaces only, also including recurrent figures of speech (tropes) and plot structures, to gain greater depth. Method-wise, other scholars have done better on other topics, such as Diane E. Goldstein's Once Upon a Virus: AIDS Legends and Vernacular Risk Perceptions (2004), which approaches AIDS as a symbolic and linguistic construction by analyzing a broad range of narratives (including children's folklore, i.e., children's jokes, sayings, rhymes, songs, riddles, games, anecdotes, etc.), dwelling extensively on the constitutive role of "contemporary legends", also called "urban legends", "modern legends" or "modern myths" (Goldstein 2004, p. 25). Goldstein is as keen as Rogers and Marshall on identifying deep-cultural structures in—in her case—vernacular perceptions of health risks: "Identifying recurrent patterns in the narratives and locating differences helps to establish cross-culturally tenacious narrative associations and associations that are more locally significant" (Goldstein 2004, p. 36). Clearly, then, even though "discourse tagging" still stands in need of methodological elaboration and specification, this approach certainly stakes out a promising line of inquiry as an example of how to make confrontations of child-authored and adult-authored children's literature productive for cultural analysis. 


\section{Beyond the Hermeneutics of Suspicion}

An even more serious liability in research into child authors is the widespread tendency to approach creative intergenerational collaboration with an attitude of categorical suspicion, which precludes the possibility of creative child agency beforehand on the basis of a theoretical parti pris. Since children's literature research is firmly rooted in the "hermeneutics of suspicion" (Ricoeur [1970] 2008), this is the biggest hurdle one is up against in this research field. Admittedly, child authorship tends to be mediated by adult editors, translators, publishers, and public relations and marketing professionals, but this does not necessarily equal the repression or silencing of children's voices in my view. For sure, a power hierarchy materializes whenever an adult processes a story of a young person in some capacity or other. But power hierarchies always come into play whenever people collaborate to achieve a specific goal. No one is ever free to say or write just anything one likes. Adult authors also have to conform to the dictates of the book market, the rules of genre, and the strictures of gatekeepers such as publishers, editors, and critics, if they want to publish their work. This means that there is only a gradual difference between adult-adult mediation and adult-child mediation.

If we grant that this is so, why then insist that things can only be right for child authors in a utopian situation to which no constraints or powerplay whatsoever apply? Nevertheless, this seems to be the point of view that some scholars defend, as in Maria Todorova's case study of the diary of an eleven -year-old Bosnian girl, Zlata Filipović, who lived through the violent break-up of the former republic of Yugoslavia. This diary was published in French and English translations before it appeared in Zlata's native tongue. Todorova (2017) argues that Zlata's diary has been corrupted and that her voice has been silenced by adult editorial interventions, such as framing by an introduction, the addition of photographs with adult-authored captions, and the insertion of explanatory comments between brackets in the body of the text and in footnotes. These interventions and add-ons provoke a rather austere verdict in Todorova:

"Not unlike Anne Frank's, Zlata's child voice in her autobiographical narrative has been repressed both by the author's desire to get published and by the adults who have decided what they assume child readers need to see in a testimony of the war. The adult agents involved in the production of the book for mass consumption, however well intentioned, ultimately are silencing — or at least muting — the child-author's voice by speaking for and about her, by translating and interpreting her rather than enabling child and adult readers to hear her". (Todorova 2017, p. 27)

Here I beg to respectfully disagree. While one could reasonably argue that some editorial interventions into Zlata's diary are less helpful than others, the phenomenon of explanatory and contextualizing introductions, inserts, and footnotes per se does not really differ from classic philological work that is meant to keep the classics such as Plato, Aristotle, Shakespeare or Erasmus alive. Philology aims to bridge the distance between past and present, as the classics come to us from a world that does not exist anymore. One may always belabor the point that some editions are more effective in bridging this gap than others and that some do a better job in recuperating the author's voice than others, and indeed, every new edition of a classical work provokes such criticisms. But to my knowledge, it is quite unusual to accuse philologists of repressing or even silencing the classics. In the case of Zlata Filipovićs diary, we are facing a different kind of gap, namely a cultural barrier between Eastern Europe and the rest of the Western world. There is precious little knowledge of the Balkan states' histories, languages, and cultures in Western Europe, let alone in the Anglosphere, as an aftereffect of the iron curtain and also because of very substantial linguistic barriers. Therefore, instead of interpreting adult editorial interventions as a form of repression and silencing, one could also regard them as just so many attempts to gain Zlata a hearing not only in her home country, but also and especially in the world beyond.

Todorova's reference to the war diary by 13-year-old Anne Frank in the quote above is a case in point. Zlata has obviously chosen to model her diary after that of her world-famous predecessor, thereby westernizing and universalizing her work herself. Anne Frank, in her turn, did exactly the 
same thing, writing not just any old diary, but a highly stylized literary work in the mode of the sentimental domestic novel, closely imitating the works of a best-selling author she greatly admired, the adolescent novels of the Joop ter Heul series by Dutch author Cissy van Marxveldt (pseudonym of Setske de Haan), published between 1919 and 1925. Van Marxveldt, in her turn, was a fervent admirer of Louisa May Alcott's Little Women (1868/1869), which was a bestseller in the Netherlands too, under the title Onder moeders vleugels (1878). But then Alcott did not invent this genre either but trod in the footsteps of mid-nineteenth century authors of female Bildingsromane such as Susan Warner, whose The Wide, Wide World, published in 1850 under the pseudonym of Elizabeth Wetherell, was arguably one of the first bestselling novels in American literary history. One might observe that child authors choose to follow the templates offered by the works they love and admire here, but in Todorova's vision, Anne Frank i another example of a child author who has been repressed by the interventions of adults, most notably her own father.

It is indeed true that Otto Frank censored those passages in his daughter's diary that expressed her emergent sexuality and her negative feelings towards her mother, Edith Frank, in the first 1947 edition. He considered these passages too private or too painful for publication, which is not so hard to understand, given his wife's tragic death on 6 January 1945 in the women's camp of Auschwitz-Birkenau, and the overall squeamishness of post-war Dutch culture. However, Todorova fails to mention that Anne Frank herself had already engaged in an extensive editing of her diary shortly before she was captured, rewriting specific passages on loose sheets of paper and pinning or pasting them over the original passages. She embarked on this project in response to a radio broadcast by Gerrit Bolkestein, the then minister for Education, Arts and Sciences during the years of war and occupation, on 29 March 1944, on Radio Oranje. In this broadcast, Bolkestein appealed to all Dutch people to carefully guard and preserve their photographs, letters, diaries, and war memorabilia at large, for these were about to become significant historical sources in the light of what people then thought was the impending liberation of the Netherlands. This appeal was not lost on Anne Frank, who dreamt of becoming a celebrated author after the war. With this aim in mind, she set out to make her work fit for publication, or, to use a different expression, she engaged in self-censorship. This is the sort of thing that authors do to be published, and child authors do it too, to the dismay of Todorova. But what is wrong with authors who want to see their work in print, whether child or adult? Or, conversely, what is the use of an unpublished manuscript? In the vein of previous practitioners of the hermeneutics of suspicion, Jacqueline Rose and Perry Nodelman to be precise, who are quoted with approval by Todorova, she is inadvertently seeking the very type of unmediated purity that we have been associating with childhood ever since Romanticism, even though their own theoretical bearings imply that such unmediated purity is nowhere to be found in society, not even amongst the very young, as our socialization begins with our very first breath and arguably even before that. In an impure and mediated world, children are bound to be impure and shaped by culture as well.

The positive alternative to the hermeneutics of suspicion would be to grant the possibility that creative collaboration between adult mediators and youthful storytellers can be potentially meaningful and of mutual advantage to both parties, and to explore the nature of this collaboration with an open mind, without jumping to conclusions about repression and silencing too quickly. A fine example of such an approach is offered by Van Lierop and Steel (2019) on the Dutch Slash Series by Querido. For sure, it would be very easy to approach this series with profound mistrust as well, given its partnerships between a celebrated, well-established author and an obscure, socially marginalized young person. And what is even more risky, the series cultivates high literary ambitions. While based on autobiographical stories, these books are explicitly presented as novels, mingling fact and fiction and employing novelistic narrative techniques. According to Edward van de Vendel, all the events narrated in the books have really happened, but not necessarily exactly in the way described, that is, not precisely in the same chronological order, while invented characters are also inserted into the life stories at hand. Todorova would probably disapprove, but Van Lierop and Steel arrive at a different conclusion, as they adopt a different approach to the matter at hand. For one, they do not abide by 
textual analysis only but also interview four sets of authors and informants involved in the Slash Series, taking into account both process and product of the intergenerational collaborations. Remarkably, Todorova has chosen not to interview Zlata Filipović, to find out what she thinks of the editorial interventions into her diary. I suspect that Filipović may actually have been quite pleased with them, if only because she did the same to other young diarists when in her early twenties, framing their war diaries by an introduction, footnotes, and comments (Filipović and Challenger 2006). For sure, interview data are never the final word on anything either, but to work with a combination of different sources and approaches makes for a more firmly grounded argument than textual analysis only.

Furthermore, Van Lierop and Steel base their analysis of both the process and product of collaboration on explicit criteria for a fair and equal collaborative process across the generations and for authentic representation of the informant in the text. Drawing on Couser (2004), they stipulate that both parties should benefit equally from the collaboration, also financially, and that informants must have given informed consent to how their life stories are dealt with in all stages of the process of writing and publication. Where the product, the representation of the informant's life story, is concerned, they argue with reference to "the ethics of form" as delineated by, amongst others, Parker (2004), that the author must aspire towards authenticity by respecting historical reality, by acknowledging that some aspects of the informant's experience are beyond representation, and by recognizing the limits of memory and the polyphony or multiplicity of self. Applying these criteria to the Slash Series, they conclude that it provides a contemporary example of collaborative life writing that contests the idea of children's literature as inherently repressive, because controlled by adults only. Criteria for satisfactory collaboration and representation are lacking in Todorova's article, which makes it difficult to determine how one could ever do it right in intergenerational collaboration. But if one can never do it right, what is the use of criticizing 'wrong' endeavors? The outcome of such an analysis will always be predictable. In short, it seems wise not to preclude the possibility of mutually beneficent creative collaboration across the generations beforehand, but rather, to engage in empirical inquiry that scrutinizes the precise nature of the collaboration with reference to explicit criteria for fairness.

\section{Conclusions: A Kinship Model of Childhood}

The main challenge facing children's literature scholars is that of childhood studies at large: How to engage in research into and with children without being overruled by ideological bias? For few societal phenomena are so heavily beset by unproven assumptions, stereotypes, anxieties, wishful thinking, and nostalgic reminiscing as children and childhood. The methodological 'dos' discussed above-discourse tagging and empirical inquiry into intergenerational collaboration-successfully operationalize Marah Gubar's kinship model of childhood, which suggests that children and adults are neither identical nor dissimilar but related to each other through family resemblances, that is, similar in some ways, different in others, while these points of convergence and divergence are subject to historical variation. As discourse tagging demonstrates, the differences make it worthwhile to listen to children's and young adults' voices on major societal issues as a set of alternative perspectives, which are at the same time similar enough for productive comparison and dialogue. The kinship model acknowledges power differences between adults and children, as family members are never on a par with each other, but it also suggests that such different degrees of dependency are not necessarily synonymous to exploitation or repression, as may be substantiated by empirical inquiry into intergenerational collaboration. Indeed, it all depends ...

Funding: No external funding has supported the writing of this article.

Acknowledgments: This paper was first presented to the international symposium Aesthetics, Pedagogies and Literatures: New Theoretical Approaches to Literary Research, hosted by the Centre for Educational Justice, Pontifícia Universidad Católica de Chile, 7 September 2018, Santiago de Chile.

Conflicts of Interest: The author declares no conflict of interest. 


\section{List of Primary Works}

Alcott, Louisa May. 1868/1869. Little Women. Boston: Roberts Brothers.

Alcott, Louisa May. 1876. Onder Moeders Vleugels: Een Verhaal van Louise M. Alcott. Translated by Aleida M. Th. Doedes and Wilhelmina Doedes-Clarisse. Amsterdam: Kirberger.

Bos, Chris, and Nicole Jongman. 2011. Korte lontjes [Short-Tempered]. Amsterdam: Querido.

Botman, Corien, and Yasmine van Leur. 2009. Hou van mij [Love me Do]. Amsterdam: Querido.

Dumon Tak, Bibi, and Castel. 2010. Latino King. Amsterdam: Querido.

Filipović, Zlata. 1994. Zlata's Diary: A Child's Life in Sarajevo. Translated by Christina Pribichevich-Zorić. London: Viking.

Filipović, Zlata, and Melanie Challenger, eds. 2006. Stolen Voices: Young People's War Diaries, from World War I to Iraq. New York: Penguin Books.

Frank, Anne. 2009. Het Achterhuis: Dagboekbrieven van 12 juni 1942-1 augustus 1944 [The Secret Annex: Diary Letters from June 12, 1942 to August 1, 1944]. Collected by Otto Frank and Mirjam Pressler. Amsterdam: Bert Bakker.

Hof, Marjolein, and Iris Kuipers. 2009. Als niemand kijkt [When No-one is Looking]. Amsterdam: Querido.

Jordan-Fenton, Christy, and Margaret Pokiak-Fenton. 2010. Fatty Legs. Toronto: Annick Press.

Jordan-Fenton, Christy, and Margaret Pokiak-Fenton. 2011. A Stranger at Home. Toronto: Annick Press.

Jordan-Fenton, Christy, and Margaret Pokiak-Fenton. 2013. When I Was Eight. Toronto: Annick Press.

Jordan-Fenton, Christy, and Margaret Pokiak-Fenton. 2014. Not My Girl. Toronto: Annick Press.

Kamara, Mariatu, and Susan McClelland. 2008. The Bite of the Mango. Toronto: Annick Press.

Kranendonk, Anke, and Lieke Kranendonk. 2008. Alles Is Weg [All is lost]. Amsterdam: Querido.

Oldenhave, Mirjam, and Cynthia van Eck. 2008. Voor jou 10 Anderen [Ten a Penny]. Amsterdam: Querido.

Rood, Lydia, and Yoyo Matthews. 2010. Miss Dakloos [Miss Homeless]. Amsterdam: Querido.

Simoen, Jan, and Alice Dupont. 2011. Ik ben Alice [I am Alice]. Amsterdam: Querido.

Soes, Jelmer, and Sanoj. 2017. Lichaam van licht [Body of Light]. Amsterdam: Querido.

Van de Vendel, Edward, and Anoush Elman. 2008. De gelukvinder [The Fortune Finder]. Amsterdam: Querido.

Van Lijssel, Melissa. 2016. Een leven vol Verdriet: Gevlucht uit Joegoslavië. S.L.: Boekscout.

Van Marxveldt, Cissy. 1918. De H.B.S. Tijd van Joop ter Heul [The High School Years of Joop ter Heul]. Amersfoort: Valkhoff \& Co.

Van Marxveldt, Cissy. 1921. Joop ter Heuls problemen [Joop ter Heuls Problems]. Amersfoort: Valkhoff \& Co.

Van Marxveldt, Cissy. 1922. Joop van Dil-ter Heul. Amersfoort: Valkhoff \& Co.

Van Marxveldt, Cissy. 1925. Joop en Haar Jongen [Joop and her Youngsters]. Amersfoort: Valkhoff \& Co.

Van Ranst, Do, and Maarten van Hove. 2011. Showbizzkiss. Amsterdam: Querido.

Warner, Susan. 1987. The Wide, Wide World. New York: The Feminist Press at the City University of New York. First published 1850.

Wilks, Rick, and Anne Millyard, eds. 1975. Wordsandwich. Toronto: Books by Kids.

Woltz, Anna, and Vicky Janssen. 2011. Meisje van Mars [Girl from Mars]. Amsterdam: Querido.

\section{References}

Alexander, Christine, and Juliet McMaster, eds. 2010. The Child Writer from Austen to Woolf. Cambridge: Cambridge University Press.

Bernstein, Robin. 2011a. Children's Books, Dolls, and the Performance of Race, or, The Possibility of Children's Literature. PMLA 126: 160-69. [CrossRef]

Bernstein, Robin. 2011b. Racial Innocence: Performing American Childhood and Race from Slavery to Civil Rights. New York: NYU Press.

Couser, Thomas G. 2004. Vulnerable Subjects: Ethics and Life Writing. Ithaca: Cornell University Press.

Craigh, Amanda. 2014. Should Children's Books Have a Happy Ending? The Guardian. June 28. Available online: https://www.theguardian.com/commentisfree/2014/jun/28/should-childrens-books-have-happyendings-observer (accessed on 30 January 2019).

Cumming, Peter, ed. 2017. 'Another Children's Literature': Writing by Children and Youth. Special issue Bookbird, vol. 55 .

Edwards, Gail, and Judith Saltman. 2010. Picturing Canada: A History of Canadian Children's Illustrated Books and Publishing. Toronto: University of Toronto Press.

Eisenhart, Christopher, and Barbara Johnstone. 2008. Rhetoric in Detail: Discourse Analyses of Rhetorical Talk and Text. Amsterdam: John Benjamins.

Ford Smith, Victoria. 2017. Between Generations: Collaborative Authorship in the Golden Age of Children's Literature. Jackson: University of Missisippi Press. 
Gill, Rosalind. 2000. Discourse Analysis. In Qualitative Researching with Text, Image, and Sound. Edited by Martin W. Bauer and George Gaskell. London: Sage, pp. 172-91.

Goldstein, Diane M. 2004. Once Upon a Virus: AIDS Legends and Vernacular Risk Perception. Utah: State University of Utah Press.

Gubar, Marah. 2009. Artful Dodgers: Reconceiving the Golden Age of Children's Literature. Oxford: Oxford University Press. Gubar, Marah. 2011. On Not Defining Children's Literature. PMLA 126: 209-16. [CrossRef]

Gubar, Marah. 2013. Risky Business: Talking about Children in Children's Literature. Children's Literature Association Quarterly 38: 450-57. [CrossRef]

Gubar, Marah. 2016. The Hermeneutics of Recuperation: What a Kinship-Model Approach to Children's Agency Could Do for Children's Literature and Childhood Studies. Jeunesse: Young People, Texts, Cultures 8: 291-310. [CrossRef]

Kittridge, Katherine. 2011. Early Blossoms of Genius: Child Poets at the End of the Long Eighteenth Century. The Looking Glass: New Perspectives on Children's Literature 15. Available online: http://bravo.lib.latrobe.edu. au/ojs/index.php/tlg/article/view/274/271 (accessed on 15 January 2019).

Landow, Georg P. 1992. Hypertext: The Convergence of Contemporary Critical Theory and Technology. Baltimore: Johns Hopkins University Press.

Marshall, Elizabeth, and Theresa Rogers. 2017. Youth, Poetry, and Zines: Rewriting the Streets as Home. Bookbird 55: 28-38. [CrossRef]

Mills, Sara. 1993. Discourses of Difference: An Analysis of Women's Travel Writing and Colonialism. London: Routledge. First published 1991.

Nikolajeva, Maria. 2010. Power, Voice, and Subjectivity in Literature for Young Readers. New York and London: Routledge.

Nodelman, Perry. 1992a. The Other: Orientalism, Colonialism, and Children's Literature. Children's Literature Association Quarterly 17: 29-35. [CrossRef]

Nodelman, Perry. 1992b. The Pleasures of Children's Literature. New York: Longman.

Parker, David. 2004. Life Writing as Narrative of the Good: Father and Son and the Ethics of Authenticity. In The Ethics of Life Writing. Edited by John Eakin. Ithaca: Cornell University Press, pp. 53-72.

Reimer, Mavis, and Charlie Peters. 2011. Ignorant and Innocent: The Childs of Common Cultural Discourse. Jeunesse 3: 88-99. [CrossRef]

Ricoeur, Paul. 2008. Freud and Philosophy: An Essay in Interpretation. Translated by Denis Savage. New Haven: Yale University Press. First published 1970.

Ritzer, George, and Nathan Jurgenson. 2010. Production, Consumption. Prosumption, Journal of Consumer Studies 10: $13-36$.

Rogers, Theresa, and Elizabeth Marshall. 2012. On the Road: Examining Self-Representation and Discourses of Homelessness in Young Adult Texts. Journal of Adolescent E Adult Literacy 55: 725-33.

Rose, Jacqueline. 1984. The Case of Peter Pan, or, The Impossibility of Children's Literature. Basingstoke and London: MacMillan.

Rudd, David, and Anthony Pavlik, eds. 2010. The (Im-)Possibility of Children's Literature: Rose Twenty-Five Years on, Special Issue. Children's Literature Association Quarterly, vol. 35.

Stillinger, Jack. 1991. Multiple Authorship and the Myth of Solitary Genius. Oxford: Oxford University Press.

Todorova, Marija. 2017. Children's Voices from War Zones: Muted by Adult Mediation. Bookbird 55: $20-27$. [CrossRef]

Tosenberger, Catherine. 2007. Potterotics: Harry Potter Fanfiction on the Internet. Gainesville: University Press of Florida.

Van de Vendel, Edward. 2006. Over adem [About Breath]. Literatuur Zonder Leeftijd 20: 118-28.

Van Lierop, Helma, and Sabine Steel. 2019. The Mingling of Teenage and Adult Breaths: The Dutch Slash-series as Intergenerational Communication. In Intergenerational Solidarity in Children's Literature. Edited by Justyna Deszcz-Tryhubczak and Zoë Jacques. Jackson: University Press of Mississipi, forthcoming.

Watson, Victor. 2000. By Children, About Children, for Children. In Where Texts and Children Meet. Edited by Eve Bearne and Victor Watson. London: Routledge, pp. 51-66.

(C) 2019 by the author. Licensee MDPI, Basel, Switzerland. This article is an open access article distributed under the terms and conditions of the Creative Commons Attribution (CC BY) license (http://creativecommons.org/licenses/by/4.0/). 